\title{
Fear and Anxiety in the Arab World
}

\author{
Michel G. Nehme \\ Gainesville, USA: University Press of Florida, 2003. 200 pages.
}

The title is certainly catchy, as not much has been written on fears and anxieties in the Arab world. Much, however, has been written on Muslims and Islam post-9/11. While some writers genuinely try to understand the various Islamic ideologies and Muslim cultures, others seek to paint a rather dim and depressing picture of Muslim societies. This book attempts to describe Arabs, as well as their fears and anxieties, in the garb of "interdisciplinary research." It is divided into seven chapters and contains a section on notes, a bibliography, and an index. The chapters address issues related to Arab politics (e.g., political identity, nationalism, and minority issues) and more general areas (e.g., religion and Arab culture). The author is a professor of political science and diplomacy at the Notre Dame University in Lebanon.

In the preface and opening chapter, Nehme introduces the growing field of political psychology, which draws upon various psychological theories to interpret human political behavior. Although he admits that the best results can be obtained through collaborative research between experts in each discipline, he dares to make an independent attempt to analyze Arab fears and anxieties from a Freudian perspective.

The book's first few pages are quite a turn-off, as many preposterous statements are made. Playing psychologist, Nehme asserts that world events are themselves natural experiments and, therefore, his assumptions are "empirically based" (p. 2). He diagnoses the problem of violence among Arabs as resulting from a "built-in consistency of anxiety" (p. 3), "most Arabs no longer appeal to God ... instead, they call on their governments for relief" (p. 4), "they are afraid of everything" (p. 7), "Arab men are afraid that their wives will be sexually attracted to other men if they leave home to work" (p. 8), and so on. He goes on to characterize suicidal tendencies among Arabs as a "death wish" that is not new in Arab history, as it develops their inner power ... through acquiring weapons, and states 
that "Arabs need enemies ... otherwise they will destroy themselves!" (p. 18). The first three chapters are devoted to demeaning Arabs by using psychoanalytic jargon that is often unclear and confusing.

Nehme is so fixated on Freud that, in chapter 4, he attempts to explain Arab nationalism in Freudian terms. He states that nationalism's central concerns are "fear, anxiety, and the conceptualization of self" and that "the great enigma that has to be accounted for once we find ourselves within the imaginary representative is molten rock of the unconscious" (p. 61). In simpler terms, he criticizes the Arab world's lack of political development, which became more evident after communism collapsed, and goes on to blame Arab nationalism for divisions, sectarianism, and even Islamic fundamentalism in the Arab world, including Iran and Afghanistan. He claims that Arab nationalism is, in fact, a myth, because of the Arabs' diversity as well as their ethnic, communal, regional, and religious disputes. Islamism, on the other hand, is on the rise and is trying to replace Arabism as a political ideology; however, Islamism is insufficient to redress valid solutions and suffers from flaws similar to Arabism.

Compelled to explain authoritarianism, ethnic and minority uprisings, and religious fundamentalism in the Middle East, he opines that Arab fears are like an "obsessional or paranoid system translated into methods whereby normal feelings of sympathy are denatured, numbed, or killed so that people can act with cruelty toward others. ... The victim is dehumanized, being a source of fear, and converted into a subhuman; a despised animal" (p. 86). This analysis of how Arabs treat minorities extends to almost all political factions, religious groups, women, languages, and ethnicities. He claims that almost all minorities in Arab states are considered alien in nationality or origin. Nehme blames the Islamic view of nature that "does not encourage a breakthrough to a modern scientific worldview" (p. 95) and its "individualism" and "supernatural reliance" for Arab society's delayed growth. Although his criticisms of Arabs and Islam are free-flowing, his assessment of the West's role in Middle East politics is almost nonexistent.

Nehme contends that psychology, as a discipline, is "completely ambiguous" in studying religion (p. 109), but continues to analyze Arab fears in the realm of religion by referring to Freudian writings. He claims that "kings and presidents in the Arab world have the power to act and speak like gods, and they are obeyed as gods; ordinary people saying they are gods are regarded as madmen and locked up in asylums, even when they are harmless" (p. 111), and, on the other hand, that "Most Arabs' concept of God is never clear" (p. 121). The closing chapter mentions the value 
of empirical surveys; but, like earlier chapters, it draws on Freudian and a few other psychoanalytic ideas to explain Arab self-image and culture.

At least for the lay person, it is important to know that Freud's work was discarded by his own disciples due to a lack of objectivity in his theory and an overemphasis on sexuality and aggression. Freud personally suffered from the Oedipus complex and Nazi aggression that shaped his theory of human nature. Much of what he wrote was based on his interactions with a handful of young and upper-class European women, and so does not necessarily pertain to people of other cultures. Even for people in the West, Freudian theory is outdated and has been revised over the years by neoFreudians and modern psychoanalysts.

Nehme, being a political scientist, seems to be unaware of this and has taken liberties in overgeneralizing aspects of Arab politics to the entire Arab population. However, if one agrees with his premise that fear and anxiety exist in the Arab world, one also would have to agree with his suggestion that such a topic should be brought to center stage and studied from an interdisciplinary perspective. Hopefully, this will result in a more objective assessment of the situation and a positive outcome for the Arab people. But this may also be true of many other cultures and societies in the non-Arab world, including the West.

A review of the notes and references suggests that besides Freud and a few other psychoanalysts whose writings are based mostly on western experiences, some references are from "scholars" who have a reputation for distorting the Arab image. What is truly regrettable is that such a book, which is intent upon slandering and promoting ethnic stereotypes, gets published without a proper check for academic honesty and by a press that is run with the taxpayers' money.

Amber Haque

Department of Psychology, International Islamic University of Malaysia

Kuala Lumpur, Malaysia 